\title{
Contextualising Feminist Global Justice Activism: A Case Study of the Gezi Park Protests
}

\author{
Zeynep Kilicoglu ${ }^{1 *}$
}

Published: March 5, 2021

\begin{abstract}
Neoliberal globalisation has not affected everywhere equally. It has deepened the socio-economic inequalities and in some regions has stimulated conservative counter-movements, which affect women more than men. Feminists in the Global Justice Movement draw attention to such issues by highlighting the interrelated nature of patriarchy and the global economic order. In this way, they could incorporate gender justice claims into the wider agenda of the Global Justice Movement and increase their influence as a political actor. This article examines the Gezi Park protests in Turkey as an example of this particular type of feminist activism and contextualises it in local forms of collective action. Utilising Eschle and Maiguashca's (2010) framework, this article explores how women experience unjust global patterns in local contexts and how oppressive patriarchal neoliberal structures at different levels speak to each other. In Turkey's context, neoliberal restructuring policies are accompanied by the promotion of religious, familial and heterosexual values along with the state's penetration into private space, which affects women disproportionally. Turkish feminists in the local Gezi Park protests responded to such regional and national contexts, whilst also defining power relations, injustices and demands in line with international frameworks of feminist antiglobalisation activisms.
\end{abstract}

Keywords: globalisation, neoliberalisation, Gezi Park protests, feminist activism, Turkey

\section{INTRODUCTION}

By creating winners and losers between states and within states, globalisation has not affected all individuals or regions equally (Karns, Mingst and Stiles, 2015). In some regions and societies, it has heightened social justice issues and widened the hierarchical gap amongst civil and corporate actors. The problem is rooted in the current corporate characteristics of globalisation: it is narrowly obtained from a Western economic context and built upon the ideas of capitalism, market rationality, competitiveness, and individualism. Relatedly, international monetary institutions such as the International Monetary Fund (IMF) and the World Bank (WB) regard globalisation as predominantly a market phenomenon and advocate for the full adaptation of neoliberal economic models in national settings to preserve and extend the contemporary, globally dominant, economic system. In other words, globalisation is perceived as identical to neoliberalisation, which is applied in a top-down fashion by international organisations and multi-national corporations without giving attention to distinct historical and cultural processes in different parts of the world. This mentality ultimately deepens economic and political injustices by prioritising the interests of corporate actors at the expense of the needs, concerns and representation of ordinary citizens.

The Global Justice Movement addresses these issues and opposes the current neoliberal global order. Distinct movements gather and work together for creating a just and fair global system for the future. Feminists are amongst these actors. They explicitly draw attention to the ways in which neoliberal globalisation intensifies gender hierarchies. Distinct feminist groups from different social and economic contexts meet in the movement and learn about each other's problems through collaboration. By establishing networks and cooperating with other movements, they aim to incorporate their authentic concerns into the general agenda of the Movement and ensure that feminist visions of equality and justice are included in this greater fight against neoliberalism. They achieve this by establishing themselves as a crucial and coherent form of collective action (Eschle and Maiguashca, 2010). In this way, they enhance their visibility and strengthen their agency. Such concerns, demands and goals also have been pursued in more recent protests: the so-called 'global wave' or the 'movements of the squares'. 
The 2013 Gezi Park protests in Turkey are a more recent manifestation of international feminist antiglobalisation activism. In May 2013, the Turkish government announced its plan to replace the Gezi Park, one of the few last green public spaces in central Istanbul, with an Ottomanist style shopping mall, as an extension of their urban gentrification projects. The brutality of the police force used against the small number of non-violent protestors, along with the aggressive stance of then Prime Minister Recep Tayyip Erdogan, triggered subsequent events which brought together various individuals and civil networks, such as students, environmentalists, feminists, LGBTI groups, religious and ethnic minorities, who are critical of the neoliberal policies of the ruling Justice and Development Party (AKP). Turkish feminist groups actively joined the protests opposing the neoliberal policies of the government that was characterised by paternalistic and patriarchal elements as well as tainted with Erdogan's masculine authoritarian political personality. Responding to regional and national issues, Turkish women also address similar issues found in the feminist anti-globalisation activism within the Global Justice Movement in terms of defining oppression mechanisms, power relations, goals, and demands.

Much work has been done to analyse the feminist concerns or the gendered dynamics of the Gezi Park protests. Scholars like Tekay and Ustun (2013) and Şimşek-Rathke (2016) mainly focus on the role of 'Gezi' in relation to the Turkish feminist movement and how Gezi benefited from the experiences of Turkish feminism. Similarly, Ünan (2014) emphasises the relation between Gezi and the wider Turkish LGBTI movement. Nahrwold and Bayhan (2013) stress the spatial dynamics of the gendered activism in the protests. Likewise, Baytok (2014) focuses on the way Turkish feminism had to integrate urban claims into their activism. There are also studies (PotuoğluCook, 2015; Erhart, 2013; Arat, 2013) that showcase a relationship between Gezi, global capitalism and feminist matters; however, none of them explicitly analyses Gezi's feminist activism in the context of the wider political dynamics of the global feminist anti-globalisation activism. Bridging this analytical gap, this article suggests conceptualising Gezi's feminist activism in relation to the transnational feminist movement mobilised within the Global Justice Movement, and aims to address the gendered injustices resulting from neoliberalism.

This article discusses how feminist anti-globalisation activism integrates its vision into the broader agenda of social justice movements, and institutionalises gender equality and gender justice as vital goals in the struggles against oppressive neoliberal regimes. In this way, feminists become a more influential political actor. Secondly, the article suggests how to appropriate the Gezi Park protests as an extension or a more local or national reflection of the Global Justice Movement, and contextualises it within the larger political dynamics of the global feminist anti-globalisation activism. In this vein, the article aims to reveal how women experience oppressive patriarchal global patterns in local and national contexts and can mobilise against them. In the first part, the article elaborates on the literature about recent global protests against neoliberal globalisation, and their commonalities with the Global Justice Movement. The second part explains the characteristics of feminist anti-globalisation activism within the Global Justice Movement, using the framework of Eschle and Maiguashca (2010) to investigate the features of this unique type of feminist activism in the $21^{\text {st }}$ century. Applying this framework, the last part of this article analyses the feminist anti-globalisation activism in the Gezi Park protests and investigates how Turkish women encounter global issues in local frameworks. Although Turkish feminists respond to the local issues which resulted from neoliberal restructuring policies during the protests, they display similarities with the feminist antiglobalisation activism at the global level in terms of defining oppression mechanisms, concerns, goals and demands. In this way, they complement and build into each other. Methodologically, this article uses secondary data and material from the current literature on the Gezi Park protests that describes the form, character and activities of the Turkish feminist anti-globalisation activism during the protests.

It could be argued that the Gezi Park protests have failed to prompt a significant change in Turkish politics as there were no major changes in the subsequent national election and plebiscite results. Also, it can be said that Turkey has become a more polarised society after the pressure among the opposition groups has dramatically increased following the failed coup attempt in 2016 (Uluğ and Acar, 2018), and the regime change to the presidential system in 2018. Yet, the Gezi Park protests are an important milestone for Turkish feminism as its actors still use the memory of 'Gezi' as a reference point to strengthen their power and galvanise in their more recent political activism about environmental degradation, violence against women and labour issues in Turkey that result from neoliberalism (Goker, 2019). Relatedly, contemporary Turkish feminism internalises claims regarding anti-globalisation into its programme, based on experiences in Gezi, and therefore perpetuates the ideals of the feminist anti-globalisation action which are further mobilised within the Global Justice Movement.

\section{HAS THE GLOBAL JUSTICE MOVEMENT COME TO AN END?}

Some of the current academic literature (see Fernández-Savater et al, 2017; Kavada and Dimitriou, 2017; Kluitenberg, 2015) explicitly theorises the Gezi Park protests under the category of the so-called 'movements of squares' rather than emphasising the protests' wider relation to the Global Justice Movement. Such sources utilise Harvey (2012) and Lefebvre's (1996) notions of the right to the city. This right calls for the redistribution of urban 
resources (including spatial ones) and the dismantling of regulatory logic and ethic of neoliberalism, as these result from the interventions of the global capitalist class in the urban sphere at the expense of restoring the truthful and meaningful representation and participation of ordinary citizens. Within this context, Kavada and Dimitriou (2017), Kluitenberg (2015) and Kaika and Karaliotas (2014) stress the spatial dynamics of these recent movements, the role of making or the production of alternative space (or reclaiming space), the centrality of space in the organisation, form, presence, and tactics of such movements and the significance of reclaiming public ownership of streets and squares, which highlights a general discontent of the representative politics and its interconnectedness with global capitalism.

The Gezi Park protests are also studied under the category of the 'global wave', which refers to the movements - such as anti-austerity or pro-democracy ones - that took place in public squares or significant national public centres in reaction to the global financial crisis in the late 2000s. There is much further debate on whether this socalled global wave should be seen as a continuation or a departure from the Global Justice Movement. Research of Daphi (2019), Giugni and Grasso (2019), and Flesher Fominaya (2017) outlines the common dynamics and argue for a continuation between the two global phenomena. First and foremost, both address the unjust structures derived from the global neoliberal economic structure along with its elites, and elucidate how they can deteriorate representative democracy. Della Porta (2012) claims participatory democracy deficits can result from the effects of global capitalist arrangements on domestic politics, such as no or fewer state interventions to mitigate the inequalities created by the market, the elitist conceptualisation of citizen participation, the heightened influence of lobbies and corporate interest groups on the domestic political arena, and deepening corruption. All these ideas display similarities with the master frame of critique pursued by the Global Justice Movement. Both movements call for equal participation, representation, and transparency. Secondly, they both pursue a great deal of cultural diversity in their rhetoric and a universalised standing on topics like human rights, peace and equality (Della Porta, 2012). They are both organised around post-material issues, which results in a common set of concerns and demands. Thirdly, they both engage in prefigurative action, in which alternative modes of economy, such as bartering and exchanging are adopted (Flesher Fominaya, 2020). Fourthly, there was a continuation of individual actors in the protests, or activist personnel. Global wave protests have definitely benefitted from the available activist networks and their experiences from the Global Justice Movement (Daphi, 2019).

As for the differences between the 'global wave' protests and the Global Justice Movement, there is a return from the transnational to the national and the local in the 'global wave' protests. In other words, there is return to the nation state as the chief provider and guarantor of true democracy. Della Porta (2012) argues there was some degree of transnational influence; however, the movements were mainly a built-in reaction to the state and ascribed more responsibility to the nation-state due to the divergences in the size, scope and timing of the financial crisis across countries. Additionally, there was minimal contact with the actors and activists in other countries. Secondly, space and its occupation become a crucial element of the global wave. While the Global Justice Movement's most salient gathering and protests were transnationally organised in counter summits, the new global wave protests utilised occupying and reclaiming public places as an important tactical element (Flesher Fominaya, 2020). This feature resonates with the literature on the spatial dynamics of such movements that I have briefly mentioned above.

Despite the obvious differences, one can detect that the master frame of critique and the main goals, concerns and demands reflect a continuation between the Global Justice Movement and the global wave. In such an interconnected global social and economic context of today, it is very hard to separate these two from each other. Yet, presenting this debate is crucial to understanding the reason for the selection of Eschle and Maiguashca's (2010) framework to investigate the unique type of feminist activisms in the Gezi Park protests. This framework was chosen because it acknowledges a continuation between the two. Most importantly, this framework provides the best theoretical characterisation of the global feminist anti-globalisation of the 21 st century, which has flourished during the Global Justice Movement, and continues to be relevant in the 'global wave' protests.

\section{GLOBAL FEMINIST ANTI-GLOBALISATION ACTIVISMS}

Moghadam (2010) argues that transnational feminist activism arose in anti-neoliberal structural contexts during the 1990s; it intended to find out how globalisation affected different women around the globe and unite them, based on common issues and demands. Therefore, feminists have a strong presence in the Global Justice Movement, with their intention to produce a fair alternative global system that is built on gender justice and equality. They assert that 'the current world system would not change without feminism and feminists cannot change the women's lives unless we change the world' (Moghadam, 2013: 163). They aim to integrate their authentic agenda and demands into the wider programme of the Global Justice Movement to seize more influence and power, as a distinct political aim (Eschle and Maiguashca, 2010). They reveal connections between gender inequality and the global capitalist system and try to convince other actors in the movement of their claims and 
critique of patriarchy. According to Eschle and Maiguashca (2010), feminist anti-globalisation activism is predominantly fighting against multiple systems of oppression (namely, patriarchy, globalised neoliberalism, and racism) in their five main subcategories, which are economic inequality, exclusion from decision-making, ecological degradation, control over women's bodies and gender-based violence. I shall now go on to discuss these five categories further.

Firstly, feminists who are engaged in this particular type of activism fight against economic inequalities. Neoliberal economic policies have deepened the inequalities and injustices for women in labour markets and exacerbated problematic global patterns in the feminisation of poverty, migration, and labour. Globalisation has normalised the exploitation of women's labour, in which women become cheap labour sources for core-capitalist countries. These countries shift their production sites to underdeveloped regions in order to exploit women of colour, who work longer hours for less money without union protection or social security (Enloe, 2004). Additionally, many countries are dependent on women to make up for neoliberal restructuring policies - such policies disrupt public services, in which women are expected to compensate for them through extending their unpaid labour into the household. Similarly, although neoliberalisation might have increased women's presence in the labour sector, their participation is not translated into a redistribution of domestic, household and child-care responsibilities (Moghadam, 2013). Even in the developed capitalist countries in the West, working women still make less money than men, work in less secure jobs and are still mainly responsible for domestic housework and childcare.

Secondly, feminists in the Global Justice Movement oppose the exclusion of women from decision-making mechanisms and demand women's greater participation in political systems. The global neoliberal order limits women's representation in national political systems at all levels via heightening ethnic, racial or class discrimination against women (Eschle and Maiguashca, 2010). Women have limited control over their lives since their decisionmaking power is replaced by masculinised global business and monetary actors, which are not concerned about representing women's interests and concerns accurately. Displacing political power from public to hegemonic economic institutions disfavours women more than men as history shows that in the absence of civil society networks, political parties that are bound by patriarchal norms are more likely to come into power and create laws that treat women as second-class citizens and limit their mobility (Moghadam, 2013). Within this context, neoliberal globalisation has enhanced gender-based discrimination and restricted women's representation in all policy areas.

Thirdly, feminists in the Global Justice Movement express their discontent about ecological degradation. Whilst neoliberal globalisation has triggered environmental damage all around the world, it has directly affected women due to restricting their access to productive resources like fuel, water, and food. Women and their relationship with the environment are vital for the wellbeing of the communities that they live in, especially in rural societies. Freetrade policies have led to the mass commodification of natural resources, which are key to the welfare and health of poor and marginalised livelihoods. Big companies have replaced the power of the indigenous women, who in the global south are traditionally responsible for the sustainability of the ecosystem to ensure the welfare of the next generations (Shiva, 2016). Within this context, feminist anti-globalisation activism has brought eco-feminist critiques to neoliberalism and has shown how ecological degradation, a consequence of global capitalism, is connected to gender inequalities.

Fourthly, feminists in the movements have protested against the enhanced desire to control women's bodies exacerbated by neoliberal globalisation. According to Eschle and Maiguashca (2010), this has mainly three dimensions: the increasing commodification of the female body, women's lack of control over their fertility, and widespread sexual harassment. Consumer culture, the backbone of the neoliberal economic system, has objectified women's bodies through allowing market actors to utilise gendered bodies in order to increase sales. The instrumentalisation of female body has normalised women's bodies into becoming tools for profit-making. Neoliberal globalisation has displaced women's control over fertility and restricted their reproductive rights. By promoting religious fundamentalism and social conservatism in some societies as counter-movements, neoliberalism eventually weakened women's power over decisions regarding their bodies and restricted women's access to abortion and contraception. Globalisation has fuelled sexual harassment by increasing the sexualised economies of prostitution, sex tourism and trafficking, which disrupts women's autonomy of their own bodies (Eschle and Maiguashca, 2010).

Lastly, feminist anti-globalisation activism calls for global peace and criticises violence against women in all of its forms (including war, domestic, gender-based and sexual violence). During the 1990s, transitional feminist networks have incorporated ideas against war and imperialism in their activism, calling for the end to all wars in order to create a better future for everyone. Additionally, the networks have revealed connections between violence, imperialism, and global capitalism. For example, the deregulation of markets and feminisation of labour have escalated gender-based violence in various ways. True (2010) discusses how neoliberalism has promoted the creation of black market economies that exploit women, like sex trafficking. Moreover, in deregulated trade zones, women work under inhumane conditions and are increasingly surveilled by employers. True argues that in 
opposition to the common view, women's participation in the labour force has suffered a backlash and substantially increased domestic violence since it has challenged the traditional power assigned to males in the private spheres and thereby increased toxic masculinities. Relatedly, feminists in the Global Justice Movement respond to these issues and disclose ways in which neoliberal economic system have heightened violence against women worldwide.

These five subcategories identified by Eschle and Maiguashca constitute the general characteristics, concerns and goals of feminist anti-globalisation activism in the Global Justice Movement. This framework will be taken as a reference point for analysing the distinct context of Turkish feminist anti-globalisation activism in the Gezi Park protests. The next section discusses how Gezi's feminist activism displays similarities with the feminist antiglobalisation activism in the Global Justice Movement and thus shows how oppressive patriarchal structures at local, national and international levels interact with each other.

\section{FEMINIST ANTI-GLOBALISATION ACTIVISM IN THE GEZI PARK PROTESTS}

In May 2013, the Turkish government announced that as a part of urban transformation and gentrification projects they are planning to replace Gezi Park, one of the last few green public spaces in central Istanbul, with an Ottomanist style shopping mall. In the first few days after the announcement, a small number of environmentalists occupied the park and demonstrated in non-violent protests. In the following days, the police brutally attacked the protestors with tear gas and burned their tents at night. The brutal police force, in addition to Prime Minister Recep Tayyip Erdogan's aggressive and authoritarian tone, triggered the events and the protests spread to the rest of the country and continued for a month. These protests are collectively called the Gezi Park protests, the largest civil uprising in the history of Turkish politics.

The Gezi Park protests can be considered as a more recent manifestation of the Global Justice Movement. It was a 'movement of movements' and had no particular person and organisation acting as a leader. Instead, it was a collective process, in which ideas and common goals delivered collaborative leadership (Eslen-Ziya and Erhart, 2015). Distinct segments of the society came together and expressed their discontent against the neoliberal policies of the AKP government. Different groups like feminists, ethnic and religious minorities, environmentalists, leftists, and LGBTI individuals all met with each other in the protests and recognised their shared grievances resulting from AKP's Islamic neoliberal state, coupled with Erdogan's authoritarian masculinist leadership (Kurtulus Korkman and Ackksoz, 2013). Consequently, the protests cannot be solely seen as environmental or urban movements. The environmental language used in the protests created a structure of opportunity, in which distinct groups could expand the agenda of the protests and communicate their political grievances and demands. Protestors took environmental values as a reference point to voice their critique against local and national regulations, which are driven by neoliberal economics. Hence, the protests expressed similar positions as the USAbased Occupy Wall Street, international anti-austerity protests and the World Social Forum, which all called for economic and social justice, democracy and fair representation for ordinary citizens.

The neoliberalisation of the Turkish economy has started in the 1980s with the eighth president of Turkey, Turgut Ozal. This economic transition has enhanced the power and presence of conservative political parties with Islamic characteristics in the national political arena. Such actors asserted that Turkey should become a part of the global capitalist system in order to achieve rapid economic growth nationally. Moreover, they believed that such integration would benefit Turkey tremendously in mitigating the effects of the 2001 economic crisis. In 2002, Erdogan and his party came into power within this crisis atmosphere, and immediately adopted the IMF's crisis management programs. Gürcan and Peker (2015) argue that such neoliberal restructuring policies are not adopted as the hegemonic international institutions prescribe them; instead, they are adjusted to geographical and cultural components in order to ensure a more successful political legitimation. They assert that in Turkey's context, this process has promoted Islamic social interventionism, as the neoliberal restructuring policies relying on Islam and Neo-Ottomanism, to ensure their local/national ideological legitimacy and coherence. This transformation of the economy was and is supported by the Islamic and moralist control of the society (and lifestyles), as the government sought ways to replace secular and democratic values and spaces with Islamic and neo-Ottomanist cultural symbols (Gürcan and Peker, 2015). The transformation of Gezi Park, which is near Taksim Square and Istiklal Avenue, areas that accommodate many bars and nightclubs, is a reflection of this transformative cultural vision.

Women have played a vital role in such policies, in which the AKP eagerly stimulated heteronormative and patriarchal values for seizing cultural validity for this economic transformation. Turkish politics has become highly sexualised and moralised since the government could legitimise its coercive and conservative policies through promoting a gendered Muslim nationalism (Potuoğlu-Cook, 2015). This idealised vision of women has translated into higher rates of gender-based violence, femicides, female unemployment and increased all forms of oppression towards women, especially the ones from different ethnic and religious backgrounds. Moreover, women's identities were systemically reduced to domestic gender roles and limited to the private sphere. As they were only allowed to exist in a conservative family sphere, the government replaced the State Ministry Responsible for Women and 
Family with the Ministry of Family and Social Policies in 2011 (Ald1kact1 Marshall, 2013). Mothers become an essential part of these structural adjustment policies as the government relied on them to give multiple births and thus secure the continuity of a cheap labour force, which would strengthen Turkey's standing in global markets (Erhart, 2013; Potuoğlu-Cook, 2015). They were also responsible for compensating for the cutbacks in public services and mitigating the austerity measures by the intensification of their unpaid domestic work in households (Potuoğlu-Cook, 2015). Women who reject conventional gender roles or make untraditional choices regarding their sexuality and reproductivity are stigmatised by the state as 'enemies of the nation' (Esen-Ziya and Erhart, 2015). For these reasons, there is a strong link between neoliberal economic restructuring and ideological patriarchy in Turkey under the AKP's rule.

Feminists confronted these problems in the Gezi Park protests and called instead for a post-patriarchal state that rejects the patriarchal protectionist, interventionist and regulatory logic of the modern state (Çınar, 2019), which has been deepened by the neoliberal transformation. In total, women constituted 51 percent of the participants in the protests (KONDA, 2013). Although many women participants were not connected directly with any political organisation and movement, IMECE Women's Solidarity Association, Yogurtcu Women Forum, Women's Initiative for Peace, the women's branch of Anti-Capitalist Muslims, and Socialist Feminist Collective can be listed as women's organisations that were present in the protests (Kaya, 2015). The protests created a political platform, in which feminists could communicate their concerns about patriarchy and its connection to neoliberalism. They introduced themselves to the other actors, which ultimately increased their influence and expanded the general cause and agenda of the protests. Gender equality was strategically identified as an essential goal for achieving economic and social justice. Within this context, this particular Turkish activism complements the global feminist anti-globalisation activism in terms of defining oppression mechanisms, power relations, injustices, goals, and demands. For demonstrating how Turkish women experience global neoliberal patriarchal patterns in local contexts, I will now utilise Eschle and Maiguashca's (2010) framework and apply their five subcategories of oppression resulting from global neoliberal order.

\section{Economic Inequality}

Although the Turkish economy is one of the fastest-growing economies globally, economic growth has not been shared equally between men and women; the proportion of female labour force participation is only 28 percent, which is far below the other OECD members average (International Civil Society Action Network, 2015). These numbers are compatible with the AKP's reconstruction of Turkish women, since the government systemically reduced women's agency to the private sphere with an intention of legitimising neoliberal restructuring. The government has refused to take women's economic potential into account and constructed them discursively solely as mothers, who are responsible for raising a religious and submissive youth (in other words, labour force) for strengthening the Turkish economy and its status in the global markets (Potuoğlu-Cook, 2015). Erdogan's advice to married couples is to have at least three children, his anti-abortion stance, and the reduction of childcare programs for working mothers have been accompanied by insufficient education for girls and labour reforms for women (Potuoğlu-Cook, 2015). Women were expected to compensate for the cuts in public spending and mitigate the austerity measures by enhancing their unpaid domestic work at home (Potuoğlu-Cook, 2015).

Although the government created new jobs via free trade policies, these jobs did not translate into welfare or security for working women. Instead, they become sources of cheap labour, whose work is being constantly exploited. Tekay and Ustun (2013) discuss how female workers have started to mobilise against these abusive conditions, for example in the women's strike in Antalya free trade zone, which also influenced many women strikes in the rest of Turkey, including those in the urban sectors such as the strike of the women personnel in Turkish Airlines (THY) in 2013. These women personnel demanded better wages and most importantly opposed the company's new regulations targeting women employee's bodies, namely the ban on red lipstick and nail polish, which were claimed to make them sexually appealing. As Tekay and Ustun continue, the THY strike was an important reflection of AKP's vision on women employment:

as it makes clear the government's vested interest is not in protecting women workers from the violations of capital, but in creating the conditions in which her body is primarily understood as the site of reproduction, and her labour is relegated to partial and flexible participation in the workforce. (Tekay and Ustun. 2013: 4)

The Gezi Park protests gave space for working-class women to express these issues and to call for equality in the workplace. For example, IMECE Women's Union, an active feminist organisation in the protests, demanded a meaningful labour reform and communicated it as an essential element of the cause of the protests. The organisation stated that: 
Sovereign capitalist power is implementing neoliberal policies on a global scale. The results of the structural transformation of capitalism and neo-liberal policies have become more visible and tangible after the nineties in Turkey. The capitalist system that fed male dominance and used gendered relations for their own benefit also put the labour force, especially that of women, off the record in the production-exploitation relations. (Kaya, 2015: 22)

Sharing such concerns, poor working-class women and women working in urban service sectors came together in the protests and demanded gender equality in the workplace and economic justice for women.

\section{Ecological Degradation and Exclusion from Decision-Making}

During the protests, the feminists drew attention to the issues related to ecological degradation exacerbated by the neoliberalisation of the Turkish economy. These issues include but are not limited to the privatisation of natural resources, nuclear power plant projects in ecologically rich coastal towns, the destruction of agricultural lands, water lands and forests for the construction of mega developments and TOKI (a housing agency controlled by the state) projects. Therefore, the feminist activists called out the capitalist class, who were backed by the government. The activists further questioned the interventionist and technocratic logic of the government about environmental matters and demanded the restoration of ordinary citizens' power over natural resources. Such ideas about the environment, resources and public control were integral to the ways feminists defined freedom and real democracy. During the protests, Women's Initiative for Peace stated in their open letter to the government, 'peace can be realized only when there is democracy, when trees are not cut down and when parks stay as parks and water as water' (Kaya, 2015: 34). Feminists asserted that the government always acts alone when it comes to environmental matters and never ask the locals for opinion, nor is it transparent about its projects. The Turkish government firmly defines a hierarchical relationship between the state, public interest, and environmental matters, in which women who question the rationality of the state become stigmatised and left out of the policy processes. Hence, the most salient theme about ecological degradation and environmental issues in Gezi's feminist activism was interrelated to another major theme: their exclusion from decision making and how such exclusion affects gendered identities.

The systemic promotion of a gendered Muslim national identity led to the exclusion of women (especially ethnically and religiously different ones) from political decision-making (including environmental matters). The development policies both in urban and rural areas were applied in a top-down fashion as the government refused to include consultations with local populations and civil society organisations in the planning processes. Such policies ultimately heightened environmental and social crises, which disrupted the livelihoods of women from ethnic minorities via displacement, and hence constrained their access to both urban and rural sources such as land, water, clean air, and energy. Subsequently, they become more vulnerable to natural disasters such as floods and earthquakes. For all these reasons, ethnic women's movements had a strong presence in the Gezi Park protests. For example, the Kurdish women's movements (such as the Kurdish Saturday Mothers and the Women's Initiative for Peace) joined the protests not only to draw attention to political and military issues related to the Kurds (Yörük, 2014) but also to criticise the neoliberal development policies (namely, mega-scale development projects such as power stations, water dams and highways) in the South East of Turkey that excluded Kurds, especially women, from the decision making process.

Moreover, Potuoğlu-Cook (2015) shows that Romani women also participated in the Gezi protests, opposing urban transformation and gentrification projects. These projects evicted poor Romani women, who mainly work in informal sectors as musicians, belly dancers, and sex workers, from their historic living and working sites in central Istanbul (namely, Sulukule). Hence, their slogan in the protests was 'This revolt is the curse of the poor gypsy that you left without a home' (2015: 107). As Potuoğlu-Cook (2015) continues AKP radicalised and sexualised these lower-class groups by evicting them from central busy urban areas in order to reconstruct Istanbul along Islamic lines as an 'honourable' global city through gentrification projects.

The LGBTI community is another example of a displaced community that actively joined the protests. The LGBTI community and many sex workers also lost their neighbourhoods to gentrification and urban transformation projects and were expelled from their living and working sites in central Istanbul. Tarlabasi is one of these neighbourhoods, in which many trans sex workers used to work and live. Hence, the displaced trans-sex workers had a strong presence in the protests, and proudly embraced their sexuality and profession in their activism. For example, 'We, the prostitutes, are hundred percent sure that the politicians are not our kids!' is one of their major slogans (Erhart, 2013: 302). As Erhart (2013: 302) argues that by using this slogan,

[t]hey were trying to undermine the sexist assumption underlying the mentality against the profession and also criticized AKP's moralism by implying that what they do for a living is much more dignified than what the politicians do. 
Furthermore, the protests created a substantial space for the LGBTI groups demanding better representation and more decision-making power in social and political platforms. This is because the protests changed the LGBTI individuals' relation with the Turkish Republic, challenged the traditional characteristics of national Turkish identity and exposed the integrated state violence towards queer citizens (Kramer, 2018). By taking issues related to neoliberalisation and environmental degradation as a reference point, the LGBTI community could express their more general concerns about their daily life, like the commission of hate crimes, violence, unemployment and discrimination to a wider audience and gain support for their visibility, representation and autonomy in public spaces and decision-making processes.

Lastly, some feminists joined the protests in order to express their discontent related to their exclusion from peace-making processes in the Kurdish, Cyprus and Syrian conflicts (International Civil Society Network Action, 2015). For example, during the protests, Women's Initiative for Peace demanded stopping the war in the Eastern Provinces, ending state violence against Kurdish women, and enabling women's equal participation in the peacemaking processes (Kaya, 2015). In this regard, Kurdish and Kemalist women stood in solidarity and called for peace at all levels of Turkish society. This was a historic turning point for the Turkish feminist movement as it became more inclusive; urban Kemalist and secular women overcame their prejudice of women from different ethnic and religious groups and embraced different radicalised identities in the movement (Canlı and Umul, 2015).

\section{The Control Over Women's Bodies}

The feminist activism in the Gezi Park protests demanded the full autonomy of women over their own bodies. As noted above, the AKP aimed to achieve ideological legitimacy for economic restructuring via creating policies on women's sexuality and fertility. Body politics was an essential element of AKP's political discourse, which aimed to morally control the society through women. A few days before the outbreak of the Gezi Park protests, AKP proposed to change the abortion law and suggested limiting women's access to abortion. Accordingly, women would need to get the consent of their male partners to have abortions in this new legal scheme. The AKP government has identified abortion as 'murder' and women, who get abortions, as 'murderers' because it relies on mothers to create an obedient workforce for the benefit of the Turkish economy (Erhart, 2013). Relatedly, Erdogan advised married couples to have at least three children for the sake of future generations. Caesarean births and abortion were labelled as 'secret plots' designed to stall Turkey's economic growth and its desire for a powerful position at the world stage (Eslen-Ziya and Erhart, 2015). Within this context, women were narrowly defined in terms of their reproductive agency, namely as mothers and wives, whose gendered bodies were utilised to support neoliberal restructuring.

Responding to this biopolitical mentality of the AKP, feminists in the protests organised the 'My Body, My Decision' campaign, in which they rejected the state intervention on their bodies and opposed to the proposed anti-abortion law. 'Resist Pregnant' is another campaign explicitly held by pregnant women in the protests (Kuras, 2015). This campaign was formed as a reaction to a Mullah sympathising with the AKP, who made a statement about the appropriate behaviours of pregnant women in public places (Tekay and Ustun, 2013). The following are slogans that are some examples that pregnant women used in the protests: 'We don't owe men or the state any children!', 'Family and the state are lies, we own our desires and our bodies!', 'We will give birth on the way to Gezi!' and 'You are not a family, you are a woman!' (Esen-Ziya and Erhart, 2015: 479). By using such slogans and images of their bodies (namely, bellies), pregnant women demanded full autonomy over their bodies via politicising their reproductive agency in the campaign.

Another demonstration in which women used their bodies was the Chain of Mothers. During the protests, the governor of Istanbul asked mothers to call their children (the protestors) home in order to protect them from the brutal police force in the park. Not surprisingly, through this call, the governor, who is a politician from the AKP, spoke to women as mothers, who in his perception have no role in the society other than taking care of their children (Tekay and Ustun, 2013). However, instead of calling them home, mothers joined their children in the park and protested with them. They created a body chain around the park and their children, to protect them from the police. Participating in the protests helped mothers recognise politicised ways of being a mother, attach new meanings to their traditional gender roles, and oppose the government's expectations from them.

Furthermore, feminists and the LGBTI activists attempted to transform the language used in the Gezi Park protests as a way to oppose AKP's body politics and to reclaim autonomy over their bodies. In general, the use of sexist and homophobic language and swear words are common in political movements in Turkey. This was also the case in the early days of the Gezi protests. However, the feminists and LGBTI groups created campaigns that specifically targeted banning the use of such language in the protests and designed workshops to teach how genderneutral political language plays an important role in embracing everyone and accomplishing the cause of Gezi. These attempts were successful in terms of convincing other groups to adopt a non-discriminatory language. For example, Çarşı, a famous fan group constituted of Beşiktaş football club supporters, gave flowers to the LGBTI groups in the protests, and apologised for using sexist swear words in their slogans (Eslen-Ziya and Erhart, 2015). 
These fan groups even participated in the Istanbul Gay Pride, which has coincided with the Gezi Park protests at Istiklal street and Taksim Square. An interview with a football fan (Ozbay and Soybakis, 2020: 44) indicates this transformative learning process:

I learned a lot from them and they made me think about my actions. I even participated in the Gay Pride event. Now, I know that feminists are not monsters. I am still your hetero football guy, but I have changed.

This was a clear moment of victory for the collective spirit of and gender activism in Gezi as hegemonic Turkish masculinity eroded to a certain extent and developed new tolerance to the presence of 'otherised' people like LGBTI individuals, vegans or ecologists, who are no longer seen as inferior (Ozbay and Soybak1s, 2020)

Lastly, women in the protests used body performances or images to criticise the AKP's intervention in their bodies. Some of these images have become symbols of the Gezi Park protests. For example, the Woman in Red, (image of a young woman in a red summer dress standing in front of a police officer spraying pepper gas directly to her face) and Lady in Black (image of a young woman standing with open arms and trying to stop the water cannon vehicle on her own) illustrated politically active and fearless Turkish women, who reject traditional gender roles and utilise their bodies to convey political messages (Arat, 2013; Erkul, 2020; Kuras 2015; Tekay and Ustun, 2013). Women's bodies moved beyond being patriarchal objects and turned into political constructs. Relatedly, the protestors defined rebellious women as the most beautiful women and named them all as 'Miss Turkey 2013' (Erhart, 2013). These bodily images were used as counter representations of AKP's vision of female bodies' appropriate role and place in the society.

\section{Violence}

Lastly, feminists in the Gezi Park protests called for an ending to all forms of violence and for achieving peace in Turkish society. Gender-based violence has been intensified by AKP's adherence to transnationally shaped neoliberal economic policies (Arat, 2013). A report by International Civil Society Network Action (2015) indicates that gender-based violence, honour killings, and femicides have steadily increased over the years, and that 42 percent of women in Turkey have experienced domestic violence by a relative. The Ministry of Family and Social Policies is silent about these problems and fails to implement laws against domestic violence and protection mechanisms for the victims while its main focus is on preventing divorces (International Civil Society Network Action, 2015). Feminists in the protests not only revolted against the normalisation of such domestic and sexual violence but also criticised the state violence against women activists, who often experience police violence and harassment during custody. Unfortunately, some women experienced police abuse and harassment in the Gezi Park protests too. However, because of the solidarity of the protestors, the women were empowered to overcome shame and expose the police abuse publicly (Tekay and Ustun, 2013).

Some of the urban women's organisations in the protests like the Yogurtcu Women's Forum addressed violence in urban life and stated that women no longer want to be concerned about harassment and rape in the urban areas (Kaya, 2015). The neoliberal restructuring created moralised and gendered public spaces, in which women going out alone at night and wearing revealing clothes were shamed and stigmatised. When there was an incident of rape or harassment society blamed the women while justifying the actions of persecutors (Kaya, 2015). This mentality eventually exacerbated and normalised gender-based violence in public spaces. During the protests, Taksim square, which is unfortunately infamous for the sexual harassment of women in massive public gatherings like the New Year's Eve celebration (Kurtulus Korkman and Ackksoz, 2013), has been transformed into a harassment-free zone by the feminist and LGBTI organisations. Such organisations educated the protestors about the risks of being made a target of gender-based violence in large public gatherings and busy districts in central Istanbul.

Similarly, as noted above, another organisation called the Women's Initiative for Peace drew attention to the state violence against women in the Eastern provinces and expressed their concerns about forced migration, violence and rape in the Kurdish conflict (Kaya, 2015). These campaigns indicated that gender-based violence is a common theme in feminist activism in the Gezi Park protests as there is a clear correlation between the increase of gender-based violence and neoliberal restructuring under the rule of the AKP.

\section{CONCLUSION}

This article has reviewed the characteristics, concerns and goals of global feminist anti-globalisation activism in the Gezi Park Protests. By convincing other groups, Turkish feminists aim to make their protest movements more responsive to gender issues. In this way, they strengthen their agency and visibility as a political actor. I consider the Gezi Park protests to be a more recent manifestation of both the Global Justice Movement and global feminist anti-globalisation activisms. Feminist groups in the Gezi Park protests responded to local and national issues while 
displaying similarities with this type of activism at the global level too, in terms of defining oppressive mechanisms, goals and demands. In this way, local and global feminist anti-globalisation activism complement and develop in relation to each other. I used Eschle and Maiguashca's (2010) framework to analyse feminist anti-globalisation activism in the protests, and to see how women experience global patterns in local contexts and mobilise against them.

The real effect of the Gezi Park protests on Turkish politics is contestable. It may be argued that the protests did not lead to a meaningful change as there were no major shifts in the national election and plebiscite results. The initial reaction of the government towards the Gezi Park protests was in organising 'Respect for National Will Meetings' as a counter-movement to claim back its power. In these meetings, the government proceeded to construct the Gezi Park protests as an anti-religious activity, a coup attempt and a dark international project against the establishment and the elite, as well as against the 'protector of representative democracy', the AKP, and its man of the people, Prime Minister Erdogan (Bilgic, 2018). Nonetheless, the government was concerned about the potential of these protests and wanted to ensure that something like 'Gezi' would never happen again. Hence, it has introduced the Internal Security Package in 2015, which broaden the authority and power of the police force (for instance, the police now have the right to open lethal fire on protestors), because in the eyes of the AKP, internal opposition is a major threat to the national security (Esen and Gumuscu, 2016).

Furthermore, many critical political events in the following years have contributed to stalling the positive effects of the Gezi Park protests. These events were, for example, the bombings in Suruc, Istanbul and Ankara between 2015 and 2016, frequent elections and plebiscites between 2015 and 2019, the destabilising effect of the reception of high numbers of Syrian refugees, and the end of the Kurdish Peace Process (Ulug and Acar, 2018). Most importantly, the failed coup attempt in 2016 led to a state of emergency status and eventually into a regime change that has increased the state repression on dissidence (Uluğ and Acar, 2018). In 2017, the AKP won the constitutional referendum for changing Turkey's political regime from parliamentary democracy to the presidential system. The new constitution gives full political power over the parliament to Erdogan, the president. Today, Erdogan's social interventionist policies still continue to target women.

That said, the Gezi Park protests have been successful in terms of creating some positive long-term effects in Turkish politics. For example, some of the forum created in the protests evolved into neighbourhood solidarity groups like the Istanbul City Defense (a local organisation fighting against urban development projects in Istanbul (Fernández-Savater et al, 2017) or United June Movement (a political organisation that aims to perpetuate the spirit of Gezi) (Uluğ and Acar, 2018). Moreover, on the individual, group and societal level, 'Gezi' had a positive emotional outcome on the participants as they become more politically active and formed connections with previously excluded groups and gained empathy towards each other (Uluğ and Acar, 2018).

Such positive outcomes have also benefited Turkish feminist movements as a whole, as the protests brought greater influence for feminist networks through giving a better platform for feminists to exchange ideas with other activist groups. A 2018 newspaper interview conducted with the women activists who participated in 'Gezi' shows that the protests gave hope, morale, and self-esteem to feminists (Avsar, 2018). Within this context, they use the memory of Gezi Park as a reference point to strengthen their autonomy and identity as a legitimate oppositional actor in their more recent political protests over the environment, transphobia, violence against women or labour issues (Goker, 2019). Most importantly, Turkish feminism has integrated claims about anti-globalisation to its own agenda. Women who formed the Flormar strike (Birgün, 2019), women organisations Ekmek ve Gül (Bread and Rose) or Eşitlikçi Kadın Platformu (Platform for Equality, Justice and Women), joined the Ida Mountain Protests in 2019 and small local women's organisations that opposed to the Canal Istanbul Project in 2020 can be seen as positive examples for the continuation of the anti-globalisation stance of Turkish feminists during Gezi - which is built on the legacy of the feminist activisms of the Global Justice Movement.

\section{REFERENCES}

Aldıkaçtı Marshall, G. (2013). The Participation of Women in the Gezi Park Protests Reflects Concerns that the Turkish Government Could Roll Back the Country's Gender Equality Reforms. LSE European Politics and Policy (EUROPP) Blog. 12 November. Available at http://eprints.lse.ac.uk/72293/. (Accessed 7 December 2020).

Arat, Y. (2013). Violence, Resistance, and Gezi Park. International Journal of Middle East Studies, 45(4), 807-809. https://doi.org/10.1017/S0020743813000962

Avsar, S. (2018). Gezi'nin Simge Kadınları: Düşlerimizi Yıktılar, Cumburiyet, 31 May. Available at: http://www.cumhuriyet.com.tr/haber/siyaset/986455/Gezi_nin_simge_kadinlari_Duslerimizi_yiktilar.html . (Accessed 26 May 2020).

Baytok, C. (2014). Integrating the 'Transforming' City into Feminist Activism: The Urban and Gender Politics in the 2000s in Turkey. Doctoral dissertation, Central European University. 
Bilgic, A. (2018). Reclaiming the National Will: Resilience of Turkish Authoritarian Neoliberalism after Gezi. South European Society and Politics, 23(2), 259-280. https:/ / doi.org/10.1080/13608746.2018.1477422

Birgün (2019). Flormar'da Anlaşma Sağland1 (editorial), Birgün, 8 March 2019. Available at: https://www.birgun.net/haber/flormar-da-anlasma-saglandi-249355. (Accessed 11 July 2020).

Canl, E. and Umul, F. (2015). Bodies on the streets: Gender Resistance and Collectivity in the Gezi revolts. Interface: A Journal for and about Social Movements, 7(1), 19-39.

Çinar, A. (2019). Negotiating the Foundations of the Modern State: The Emasculated Citizen and the Call for a Post-Patriarchal State at Gezi protests. Theory and Society, 48(3), 453-482. https://doi.org/10.1007/s11186-01909350-8

Daphi, P. (2019). The Global Justice Movement in Europe, in C. Flesher Fominaya and R. A. Feenstra (eds), The Routledge Handbook of Contemporary European Social Movements: Protest in turbulent times (pp. 142-154). London: Routledge. https://doi.org/10.4324/9781351025188-11

Della Porta, D. (2012). Mobilizing against the Crisis, Mobilizing for 'Another Democracy': Comparing Two Global Waves of Protest. Interface: A Journal for and about Social Movements, 14(1), 274-277.

Enloe, C. (2004). The Curious Feminist: Searching for women in a new age of empire. Berkeley: University of California Press. https://doi.org/10.1525/9780520938519

Erhart I. (2013). Biopolitics and the Gezi protests, in T. Chou (ed), Proceedings of the 2013 International Conference on the Modern Development of Humanities and Social Science (pp. 301-303). Hong Kong: Atlantis Press. https://doi.org/10.2991/mdhss-13.2013.79

Erkul, S. (2020). Activist Feminism in Turkey, Represented Through the Caricatures of Bayan Yam Magazine. Feminist Encounters: A Journal of Critical Studies in Culture and Politics, 4(1), 08. https://doi.org/10.20897/femenc/7912

Eschle, C. and Maiguashca B. (2010). Making Feminist Sense of the Global Justice Movement. Plymouth: Rowman \& Littlefield Publishers.

Esen, B. and Gumuscu, S. (2016). Rising Competitive Authoritarianism in Turkey. Third World Quarterly, 37(9), 1581-1606. https://doi.org/10.1080/01436597.2015.1135732

Eslen-Ziya, H. and Erhart, I. (2015). Toward Postheroic Leadership: A Case Study of Gezi's Collaborating Multiple Leaders. Leadership, 11(4), 471-488. https:/ / doi.org/10.1177/1742715015591068

Fernández-Savater, A., Flesher Fominaya, C., Carvalho, L., Çiğdem, Elsadda, H. El-Tamami, W., Horrillo, P., Nanclares, S., and Stavrides, S. (2017). Life after the Squares: Reflections on the Consequences of the Occupy movements. Social Movement Studies, 16(1), 119-151. https:/ / doi.org/10.1080/14742837.2016.1244478

Flesher Fominaya, C. (2017). European Anti-Austerity and Pro-Democracy Protests in the Wake of the Global Financial Crisis. Social Movement Studies, 16(1), 1-20. https://doi.org/10.1080/14742837.2016.1256193

Flesher Fominaya, C. (2020). Social Movements in a Globalized World. Basingstoke: Palgrave Macmillan/Red Globe Press.

Giugni, M. and Grasso, M. (2019). Nothing is Lost, Nothing is Created, Everything 'Is Transformed': From Labour Movements to Anti-Austerity Protests, in C. Flesher Fominaya and R. A. Feenstra (eds), The Routledge Handbook of Contemporary European Social Movements: Protest in turbulent times (pp. 129-141). London: Routledge. https://doi.org/10.4324/9781351025188-10

Goker, Z. G. (2019). Memories, Stories and Deliberation: Digital Sisterhood on Feminist Websites in Turkey. European Journal of Women's Studies, 26(3), 313-328. https:/ / doi.org/10.1177/1350506819855414

Gürcan, E. C. and Peker E. (2015). Challenging Neoliberalism at Turkey's Gezi Park: From private discontent to collective class action. New York: Springer. https://doi.org/10.1057/9781137469021

Harvey, D. (2012). Rebel Cities: From the right to the city to the urban revolution. New York, London: Verso Books.

International Civil Society Action Network. (2015). Resisting the New Conservatism: Women's campaigns for rights, peace and participation in Turkey. Washington: ICAN.

Kaika, M. and Karaliotas, L. (2014). The Spatialization of Democratic Politics: Insights from Indignant Squares. European Urban and Regional Studies, 23(4), 556-570. https:/ / doi.org/10.1177/0969776414528928

Karns, M. P., Mingst A. K., and Stiles K. W. (2015). International Organizations: The politics and processes of global governance. Colorado: Lynne Rienner Publishers.

Kavada, A. and Dimitriou O. (2017). Protest Spaces Online and Offline: The Indignant Movement in Syntagma Square, in G. Brown, A. Feigenbaum, F. Frenzel and P. McCurdy (eds), Protest Camps in International Context: Spaces, infrastructures and media of resistance (pp.71-90). Bristol: Policy Press. https://doi.org/10.2307/j.ctt1t89745.10

Kaya, Z. (2015). Women in the Gezi Protests. Master's dissertation, Leiden University.

Kluitenberg, E. (2015). Affect Space - Witnessing the Movement(s) of the Squares'. Available at: https://www.onlineopen.org/affect-space (Accessed 7 January 2021).

KONDA. (2013). Gezi Parke Arastırmasi: Kimler, neden oradalar ve ne istiyorlar? Istanbul: KONDA. 
Kramer, P. G. (2018). The Queer Common: Resisting the Public at Gezi Park and Beyond, in C. Agius and D. Keep (eds), The Politics of Identity: Place, space and discourse (pp. 199-216). Manchester: Manchester University Press. https://doi.org/10.7228/manchester/9781526110244.003.0012

Kuras, J. (2015). \#DIRENHAMILE: Pregnancy, Morality, and Resisting Discourses of Seclusion at the Gezi Park Protests. Master's dissertation, The University of North Carolina.

Kurtulus Korkman, Z. and Aciksoz S. C. (2013). Erdogan's Masculinity and the Language of the Gezi Resistance. Jadaliyya blog. 22 June. Available at https://www.jadaliyya.com/Details/28822. (Accessed 5 December 2020).

Lefebvre, H. (1996). Right to the city, in E. Kofman and E. Lebas (eds), Writings on Cities (pp. 147-159). Oxford: Blackwell.

Moghadam, V. M. (2010). Transnational activism, in L. J. Shepherd (eds), Gender Matters in Global Politics: A feminist introduction to international relations (pp. 292-306). Abingdon: Routledge.

Moghadam, V. M. (2013). Globalization and Social Movements: Islamism, Feminism, and the Global Justice Movement. Plymouth: Rowman \& Littlefield Publishing.

Nahrwold, J. And Bayhan, S. (2013). Gezi Resistance from a Spatial and Gendered Perspective. Anuari Del Conflicte Social, 3, 117-151.

Ozbay, C. and Soybakıs O. (2020). Political Masculinities: Gender, Power, and Change in Turkey. Social Politics: International Studies in Gender, State \& Society, 27(1), 27-50.

Potuoğlu-Cook, Ö. (2015). Hope with Qualms: A Feminist Analysis of the 2013 Gezi Protests. Feminist Revien 109(1), 96-123. https:// doi.org/10.1057/fr.2014.56

Shiva, V. (2016). Staying Alive: Women, ecology, and development. Berkeley: North Atlantic Books.

Şimşek-Rathke, L. (2016). Youth Unrest, Intergenerational Solidarity and Feminist Impetus in Social Movements: The Case in Istanbul. Afriche Orienti, 78-101.

Tekay, C. and Ustun Z. (2013). A Short History of Feminism in Turkey and Feminist Resistance in Gezi. Paper presented at Talk Turkey Conference: Rethinking Life since Gezi, The New School University, New York October 4-5.

True, J. (2012). The Political Economy of Violence Against Women. New York: Oxford University Press. https://doi.org/10.1093/acprof:oso/9780199755929.001.0001

Uluğ, Ö. M., and Acar Y. G. (2018). What Happens After the Protests? Understanding Protest Outcomes Through Multi-Level Social Change. Peace and Conflict: Journal of Peace Psychology, 24(1), 44-53. https://doi.org/10.1037/pac0000269

Ünan, A. D. (2015). Gezi Protests and the LGBT Rights Movement: A Relation in Motion, in A. Yalcintas (ed), Creativity and Humour in Occupy Movements: Intellectual disobedience in Turkey and beyond (pp.75-94). London: Palgrave Macmillan. https://doi.org/10.1057/9781137473639_5

Yörük, E. (2014). The long summer of Turkey: The Gezi uprising and its historical roots. South Atlantic Quarterly, 113(2), 419-426. https:/ / doi.org/10.1215/00382876-2644203

Citation: Kilicoglu, Z. (2021). Contextualising Feminist Global Justice Activism: A Case Study of the Gezi Park Protests. Feminist Encounters: A Journal of Critical Studies in Culture and Politics, 5(1), 13. https://doi.org/10.20897/femenc/9750

Copyright (C) 2021 by Author/s and Licensed by Lectito BV, Netherlands. This is an open access article distributed under the Creative Commons Attribution License which permits unrestricted use, distribution, and reproduction in any medium, provided the original work is properly cited. 